\title{
DafA Cycles Between the DnaK Chaperone System and Translational Machinery
}

\section{Georgeta L. Dumitru1, Yvonne Groemping ${ }^{2}$, Dagmar Klostermeier ${ }^{3}$, Tobias Restle ${ }^{1}$, Elke Deuerling ${ }^{4}$ and Jochen Reinstein ${ }^{2 *}$}

\author{
${ }^{1}$ Max-Planck-Institut für \\ molekulare Physiologie \\ Abteilung physikalische \\ Biochemie, Otto-Hahn-Str. 11 \\ 44227 Dortmund, Germany \\ ${ }^{2}$ Max-Planck-Institute for \\ Medical Research, Department \\ of Biomolecular Mechanisms \\ Jahnstrasse 29 D-69120 \\ Heidelberg, Germany \\ ${ }^{3}$ University of Bayreuth \\ Lehrstuhl für \\ Experimentalphysik $I V$ \\ Universitätsstr. 30, 95447 \\ Bayreuth, Germany \\ ${ }^{4}$ University of Heidelberg \\ $\mathrm{ZMBH}$, Im Neuenheimer Feld \\ 282, 69120 Heidelberg \\ Germany
}

\begin{abstract}
DafA is encoded by the dnaK operon of Thermus thermophilus and mediates the formation of a highly stable complex between the chaperone DnaK and its co-chaperone DnaJ under normal growth conditions. DafA $_{\text {Tth }}$ contains 87 amino acid residues and is the only member of the DnaK $_{\text {Tth }}$ chaperone system for which no corresponding protein has yet been identified in other organisms and whose particular function has remained elusive. Here, we show directly that the $D_{n a K} K_{T t h}-D_{n a J} J_{T h}-$ DafA $_{\text {Tth }}$ complex cannot represent the active chaperone species since DafA $_{\text {Tth }}$ inhibits renaturation of firefly luciferase by suppressing substrate association.

Since DafA $A_{\text {Tth }}$ must be released before the substrate proteins can bind we hypothesized that free Daf $A_{T t h}$ might have regulatory functions connected to the heat shock response. Here, we present evidence that supports this hypothesis. We identified the $70 \mathrm{~S}$ ribosome as binding target of free DafA $\mathrm{T}_{\mathrm{Tth}}$. Our results show that the association of DafA $\mathrm{A}_{\mathrm{Tth}}$ and $70 \mathrm{~S}$ ribosomes does not require the participation of $D_{n a K_{T t h}}$ or $D_{n a t} J_{T t h}$. On the contrary, the assembly of $\mathrm{DnaK}_{\mathrm{Tth}}-\mathrm{DnaJ}_{\mathrm{Tth}}-\mathrm{DafA}_{\mathrm{Tth}}$ and ribosomeDaf $_{\text {Tth }}$ complexes seems to be competitive. These findings strongly suggest the involvement of Daf $\mathrm{A}_{\mathrm{Tth}}$ in regulatory processes occurring at a translational level, which could represent a new mechanism of heat shock response as an adaptation to elevated temperature.
\end{abstract}

Keywords: chaperone; heat shock; ribosome; folding; regulation

\section{Introduction}

The Hsp70 chaperone machinery is one of the most conserved chaperone families across the archaeal, bacterial and eukaryotic domains. DnaK, the eubacterial Hsp70 homolog, is an ATPdependent molecular chaperone that functions together with the co-chaperones, DnaJ and GrpE, to mediate protein folding and other essential processes in the cell, under both normal and environmentally stressful growth conditions. The DnaK systems participate in folding of nascent polypeptide chains, protein transport across membranes, proteolysis, assembly of multi-domain protein structures, disassembly of protein aggregates, cell

Abbreviations used: IRs, inverted repeat sequences; $\mathrm{TF}$, trigger factor; RAC, ribosome-associated complex.

E-mail address of the corresponding author: jochen.reinstein@mpimf-heidelberg.mpg.de division, DNA replication and regulation of the heat shock response. ${ }^{1-5}$

A paradigm DnaK system is the one of Escherichia coli, which consists of the molecular chaperone DnaK and the two cohort proteins: the ATPasestimulating protein DnaJ ${ }^{1,6}$ and the nucleotide exchange factor GrpE.7,8

The DnaK system from Thermus thermophilus presents a more complex protein organization derived from the presence of DafA (DnaK-DnaJ association factor A) as an accessory component. ${ }^{9}$ This $8.7 \mathrm{kDa}$ co-chaperone constitutes a mandatory element required in T. thermophilus for the stabilization of the DnaK-DnaJ complex. Under normal growth conditions, about half of the total cellular amount of DnaK $\mathrm{Tth}_{\text {th }}$ is found associated with DnaJ $\mathrm{Tth}_{\text {th }}$ and DafA $_{\mathrm{Tth}}$ in a ternary complex comprising three copies of each protein species. ${ }^{9,10}$ The formation of this heterotrimeric complex seems to occur in a highly synergic manner since binary complexes of

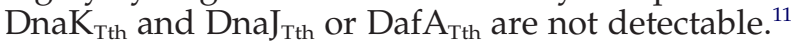


It was speculated that a protein with a similar function in mediating DnaK ${ }_{\mathrm{Tth}}-\mathrm{DnaJ}_{\mathrm{Tth}}$ interaction may exist in other organisms as well. ${ }^{9}$ Evidence that could confirm this suggestion is, at least until present, not available. The amino acid sequence of Daf $_{\text {Tth }}$ shares no significant homology with any other protein found in the current databases. Moreover, the high degree of sequence homology between DnaK, DnaJ and GrpE from T. thermophilus and their counterparts from the moderately thermophilic Meiothermus rubber $(81.96 \%$ for DnaK, $58 \%$ for DnaJ and $49.72 \%$ for GrpE) does not imply the existence of a corresponding DafA homolog. DnaK and DnaJ from M. rubber associate into a stable complex in an ATP-dependent manner without the help of an accessory protein. ${ }^{12}$ In comparison, the assembly of DnaK-DnaJ-DafA complex in T. thermophilus is a nucleotide-independent process. ${ }^{11}$

Except for its mediating role in the formation of DnaK $_{\text {Tth }}-$ DnaJ $_{\text {Tth }}-$ DafA $_{\text {Tth }}$ complex, little is known about the specific function of DafA $A_{\text {Tth }}$. Studies with fluorescent peptides indicated that $\mathrm{DafA}_{\mathrm{Tth}}$ is interfering with substrate binding to DnaK ${ }_{\text {Tth }}{ }^{11}$ Here, we show directly that DafA $_{\text {Tth }}$ interferes with binding of luciferase, a model protein-substrate for the DnaK system in general. Since this implies that DafA $_{\text {Tth }}$ is displaced by the high concentration of protein-substrate that is abundant under heat shock conditions, we tried to identify additional interaction partners of free Daf $_{\text {Tth }}$ with an emphasis on potential regulatory roles. From these studies it became evident that DafA $_{\text {Tth }}$ interacts with the $70 \mathrm{~S}$ ribosome from $T$. thermophilus possibly also in combination with rRNA.

\section{Results}

\section{DafA $_{\text {Tth }}$ co-elutes with RNA molecules during purification}

We observed that after a size exclusion step included in the DafA $\mathrm{A}_{\text {th }}$ purification protocol the absorption spectrum was exhibiting a maximum at $260 \mathrm{~nm}$ instead of $280 \mathrm{~nm}$, indicating a high nucleotide or nucleic acid content. To test whether this component might be a polynucleotide or a larger nucleic acid it was analyzed via ureadenaturing polyacrylamide gels used for nucleic acids. Since this component could be stained with ethidium bromide it appears to be indeed a nucleic acid. To identify the nature of this molecule, it was purified from DafA $\mathrm{T}_{\text {Th }}$ sample under RNase-free conditions and treated with different nucleases. As seen in Figure 1, after incubation of this sample with RNaseA the bands disappeared, indicating that the nucleic acids co-purified with DafA $\mathrm{A}_{\mathrm{Tth}}$ are RNAs of various lengths.

\section{Daf $_{\text {Tth }}$ inhibits chaperone-assisted refolding}

Studies with fluorescent model peptides have

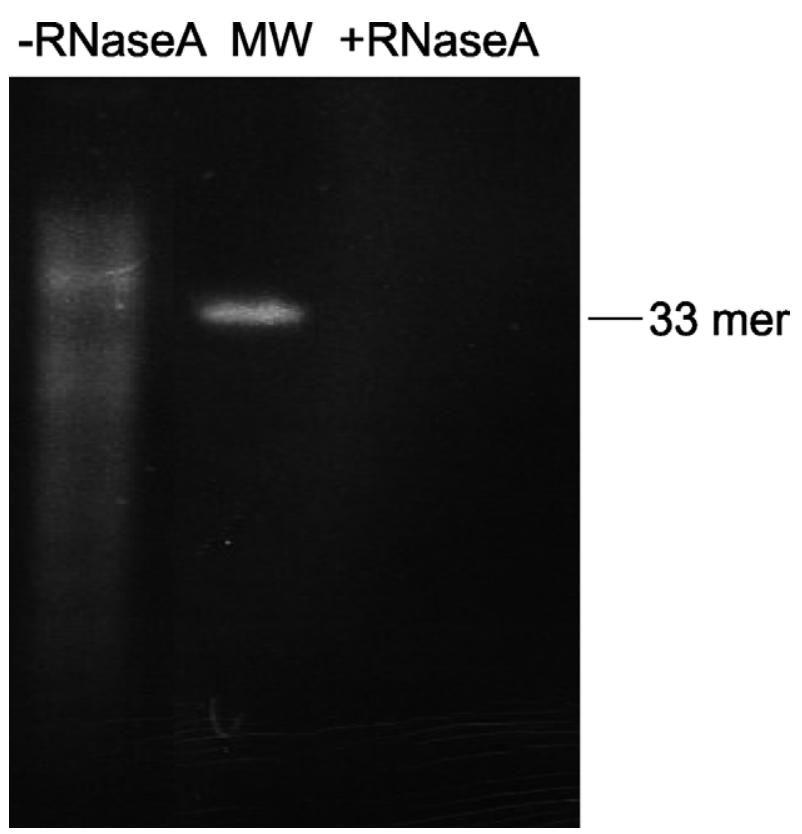

Figure 1. Daf $\mathrm{A}_{\text {Tth }}$ co-elutes with RNAs in gel filtration. The component with high absorption at $260 \mathrm{~nm}$ was purified and applied on a denaturing gel for nucleic acids. In the absence of RNaseA ( - RNaseA lane) a broad pattern of bands was visible with ethidium bromide staining. RNaseA digestion of this sample (+RNaseA lane) leads to their disappearance from the gel. For a rough approximation of the length of these RNAs a 33-mer RNA was used as a molecular mass marker (MW).

indicated that binding of DafA $_{\text {Tth }}$ and substrate proteins may be competitive. ${ }^{11}$ Here, we tested this by directly measuring the influence of DafA $\mathrm{A}_{\text {Th }}$ on the renaturation of GdnHCl-denatured firefly luciferase, a model system that was also used with the DnaK system from E. coli. ${ }^{13,14}$ The DnaK ${ }_{\text {Tth }}$ system, though originating from an organism that lives at about $75^{\circ} \mathrm{C}$, is fully functional at $30^{\circ} \mathrm{C}$ in a continuous luciferase refolding assay. ${ }^{15}$ Although the DnaK $\mathrm{T}_{\mathrm{Tth}}$ chaperone cycle is slightly slower, the maximal yield of active luciferase appears to be comparable in both systems. ${ }^{15}$

The addition of DafA $\mathrm{Dth}_{\mathrm{Th}}$ to the $\mathrm{DnaK}_{\mathrm{Tth}}$-refolding mixture has dramatic consequences on the luciferase renaturation (Figure 2). When a 25 -fold excess of DafA $\mathrm{T}_{\mathrm{Tth}}$ is present immediately after dilution of luciferase into assay buffer, the reactivation yield is close to nil. Addition of $\operatorname{DafA}_{\mathrm{Tth}}$ at later times (between 15 minutes and 120 minutes) leads to an abortion of refolding, indicating that DafA $\mathrm{A}_{\text {Tth }}$ suppresses the association of substrates. This result shows directly that DafA $A_{\text {Tth }}$ although it is essential to mediate the interaction of DnaJ ${ }_{\mathrm{Tth}}$ and DnaK $\mathrm{Tth}_{\mathrm{T}}$, is not part of the active chaperone system.

\section{Insertion of the cysteine residue at the $\mathbf{N}$ terminus does not alter the properties of DafA $_{\text {Tth }}$}

DafA $_{\text {Tth }}$ is devoid of cysteine residues, as are all the other members of the DnaK chaperone system 


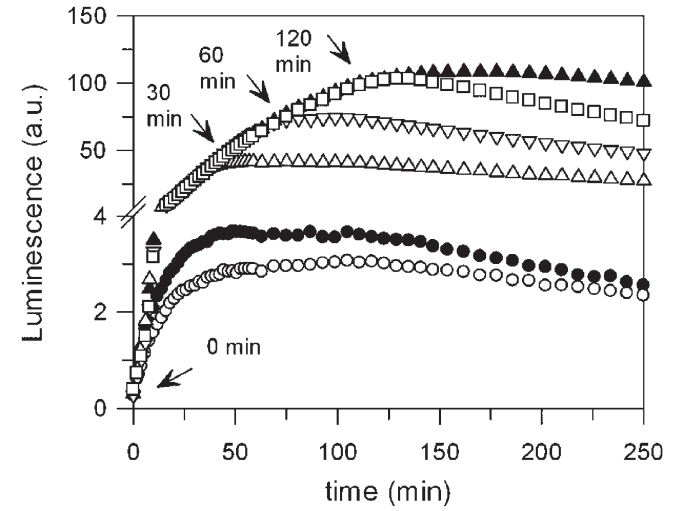

Figure 2. Daf $\mathrm{A}_{\text {Tth }}$ inhibits luciferase refolding. After incubation in $5 \mathrm{M} \mathrm{GdnHCl}$ unfolded firefly luciferase was diluted 125-fold into assay buffer containing $3.2 \mu \mathrm{M}$ DnaK $_{\text {Tth }}, 0.4 \mu \mathrm{M}$ DnaJ $_{\mathrm{Tth}}$ and $0.2 \mu \mathrm{M} \mathrm{GrpE}_{\mathrm{Tth}}$. At different times as indicated by arrows $(0(\bigcirc), 30(\triangle), 60(\nabla)$ and 120 ( $\square$ ) minutes), $2.3 \mu \mathrm{M}$ DafA $_{\text {Tth }}$ was added. Refolding of luciferase in the absence of chaperones (-) or in the presence of the DnaK ${ }_{\text {Tth }}$ system without DafA $\mathrm{A}_{\text {Tth }}(\mathbf{\Lambda})$ served as controls. The assay was performed continuously at $30{ }^{\circ} \mathrm{C}$ as described. ${ }^{15}$ Refolding in the absence of Daf $_{\text {Tth }}$ was set to $100 \%$.

from T. thermophilus. Taking advantage of this we engineered a cysteine mutant by replacing Ser14 of DafA $\mathrm{Tth}_{\mathrm{Th}}$. The mutant behaves like DafA $\mathrm{Tth}_{\mathrm{Tth}}$ during overexpression in E. coli and the purification procedure. To avoid oxidation of the engineered thiol group, the purification was carried out under reducing conditions.

In order to verify the functional integrity of this cysteine variant we investigated the formation of the DnaK $\mathrm{Tth}_{\mathrm{Th}}-\mathrm{DnaJ}_{\mathrm{Tth}}-\mathrm{DafA}_{\mathrm{Tth}}-\mathrm{S} 14 \mathrm{C}$ complex. Native gel electrophoresis showed that incubation of the three proteins under native conditions leads to the appearance of a band characteristic for this heterotrimeric complex ${ }^{9,10}$ (data not shown). Also, the addition of DafA $_{\text {Tth }}-\mathrm{S} 14 \mathrm{C}$ to the luciferase assay (under the conditions described above) exhibits the same inhibitory effect on luciferase refolding as DafA $A_{\text {Tth }}$ (data not shown). Both results demonstrate that this point mutation does not alter the functional properties of DafA $\mathrm{A}_{\mathrm{Tth}}$ and the mutant was therefore used for further analyses.

\section{Daf $_{\mathrm{Tth}}$ binds in vitro to the $70 \mathrm{~S}$ ribosomes in sucrose cushion assay}

As shown previously, during purification DafA $_{\text {Tth }}$ co-elutes with various RNAs from the gel filtration column. This was the first indication that $\mathrm{DafA}_{\mathrm{Tth}}$ 's role in mediating DnaK $\mathrm{Tth}_{\mathrm{Th}}-\mathrm{Dna}_{\mathrm{Tth}}$ interaction might be not the sole function of this protein. Since there is no considerable homology between the amino acid sequences of DafA $A_{T t h}$ and other proteins found in the actual databases, we tried to obtain more information about another potential role of DafA $_{\text {Th }}$ using its amino acid sequence and the bioinformatical tools available. According to the secondary structure prediction program based on the GOR method ${ }^{16}$ DafA $_{\text {Tth }}$ has a helix-loop-helix secondary structure, which is a feature of many DNA/RNA-binding proteins. Consistently, prediction of the tertiary structure using the 3D-PSSM method ${ }^{17}$ suggests that the fold of DafA $_{\text {Tth }}$ might be related to a DNA or RNA-binding protein. Since some sequence homology exists between DafA $_{\text {Tth }}$ and the transcriptional regulator HspR from Streptomyces coelicolor (21\% amino acid sequence identity), their similar genetic localization within the DnaK operon was considered during the search for functional homo$\operatorname{logs}$ of DafA $\mathrm{Tth}_{\text {. }}$

To test whether DafA $\mathrm{A}_{\text {Tth }}$ could act as a transcriptional regulator that might be connected to heat shock conditions, a series of potential interaction partners was investigated. Candidates for DafA $\mathrm{Ath}^{-}$ binding were: the promotor of the DnaK $\mathrm{T}_{\mathrm{Th}}$ operon (including -35 and -10 cassettes), some inverted repeats localized upstream of the DnaK promotor operon and a special type of RNA, the pseudoknot RNA, which is a substrate for HIV-1 reverse transcriptase. $^{18}$ Except for the last one, none of these molecules showed any interaction with DafA $_{\text {Tth }}$. In a gel shift assay it seemed that DafA $A_{\text {Tth }}$ was binding the radiolabeled pseudoknot RNA but the interaction is characterized by an extremely low affinity and might represent non-specific RNA binding (data not shown).

Given the fact that our results did not confirm the hypothesis of a transcriptional regulatory role of Daf $\mathrm{A}_{\mathrm{Tth}}$, the possibility that it might be involved in translational control was also considered. Thus, we checked for the existence of an interaction between DafA $\mathrm{Tth}_{\text {th }}$ and T. thermophilus $70 \mathrm{~S}$ ribosomes. For this we made use of a sucrose cushion assay, a tool that offers direct information about a potential binding event. Because DafA $\mathrm{A}_{\mathrm{T} \text { th }}$ is prone to aggregation it was necessary to establish ultracentrifugation conditions under which DafA $\mathrm{A}_{\mathrm{Tth}}$ precipitation did not interfere with ribosome-DafA $A_{T \text { th }}$ complex formation. These conditions were obtained by raising the sucrose concentration to $30 \%$ and by using twofold volumes of sucrose over the volume of sample. These experiments were performed using either DafA $\mathrm{A}_{\mathrm{Tth}}$ followed by immunoblotting detection or using the Alexa488labeled DafA $\mathrm{Tth}_{\mathrm{T}}-\mathrm{S} 14 \mathrm{C}$ mutant and subsequent fluoroimaging analysis, which provided an easier and faster evaluation of the data. Prior to ultracentrifugation the components were incubated for 15 minutes at $30^{\circ} \mathrm{C}$ or at $70{ }^{\circ} \mathrm{C}$, a temperature closer to the optimal growth conditions of T. thermophilus. As seen in Figure 3, in both immunoblotting (A) and fluoroimaging (B) approaches, in the absence of ribosomes Daf $A_{T \text { th }}$ remains in the supernatant (Figure 3(A), lanes 3 and 11; Figure 3(B), lane 3), while in the samples containing both components DafA $\mathrm{A}_{\mathrm{Tth}}$ is also found in the pellet together with the ribosomes (Figure 3(A), lanes 6 and 8; Figure 3(B), lanes 6) indicating that $70 \mathrm{~S}$ ribosome-DafA $\mathrm{A}_{\text {Th }}$ complexes were formed. The interaction seems to be 


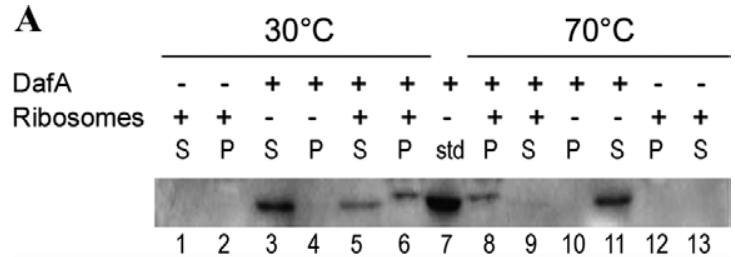

B

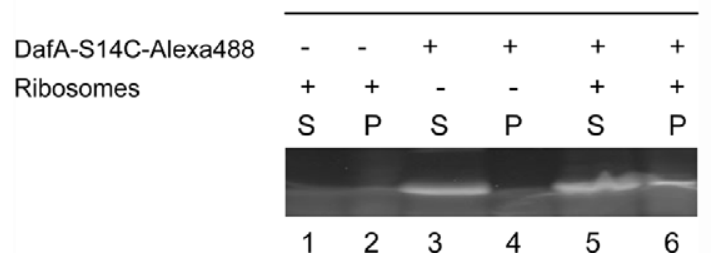

Figure 3. Sucrose cushion assay: in vitro binding of DafA $_{\text {Tth }}$ and Alexa488-labeled DafA $\mathrm{A}_{\text {Tth }}-\mathrm{S} 14 \mathrm{C}$ to T. thermophilus $70 \mathrm{~S}$ ribosomes. (A) Immunoblotting. $30 \mu \mathrm{M}$ DafA $_{\text {Tth }}$ was incubated at $30^{\circ} \mathrm{C}$ or $70^{\circ} \mathrm{C}$ with $2 \mu \mathrm{M} 70 \mathrm{~S}$ ribosomes for 15 minutes and applied on two volumes of $30 \%$ sucrose cushion followed by ultracentrifugation to re-isolate the ribosomal particles. Equal volumes of supernatants $(S)$ and ribosomal pellets $(P)$ were separated by SDS-PAGE and subjected to Western blotting using rabbit anti-DafA $A_{\text {Tth }}$ antibodies. DafA $A_{\text {Tth }}(2 \mu \mathrm{M})$ was applied as a standard (std). (B) Fluoroimaging. Alexa488-labeled DafA $_{T \text { Th }}-\mathrm{S} 14 \mathrm{C}$ at $5 \mu \mathrm{M}$ final concentration was incubated 15 minutes with $1 \mu \mathrm{M} 70 \mathrm{~S}$ ribosomes at $37^{\circ} \mathrm{C}$. After ultracentrifugation on $30 \%$ sucrose cushion the pellets $(\mathrm{P})$ and the supernatants $(\mathrm{S})$ were TCA-precipitated and subsequently applied to SDSPAGE. The fluorescence of the bands was detected directly from the gel using a fluorescence scanner.

temperature-independent in vitro as incubation of the components at $30{ }^{\circ} \mathrm{C}$ or at $70{ }^{\circ} \mathrm{C}$ does not show significant changes in the intensity of the bands corresponding to the ribosomal pellets (Figure 3(A), lanes 6 and 8). This result is in a way comparable to the weak dependence on temperature of nucleotide binding to DnaK $\mathrm{Tth}^{19}{ }^{19}$ We cannot exclude however, that the centrifugation procedure that followed incubation at different temperatures is partially responsible for this observation. Temperature independence was already observed for the DnaK $_{\text {Tth }}$ system during luciferase refolding, the thermophilic chaperone machinery being fully functional at $30^{\circ} \mathrm{C}^{15}$ There is a very faint DafA $\mathrm{A}_{\text {Tth }}$ band in the lane derived from ribosome plus DafA $_{\text {Tth }}$ supernatant (Figure 3(A), lane 9). This is not associated with an amplified signal in the corresponding pellet lane that could indicate a higher degree of binding. We therefore consider it as the result of protein loss during manipulation prior to SDS-PAGE. Because no protease inhibitors have been used during these experiments the protein loss here could be also the consequence of protein degradation.

\section{Daf $A_{\text {Tth }}$ binds in vitro to the $70 \mathrm{~S}$ ribosomes in analytical gel filtration experiments}

To further analyze the complex formation
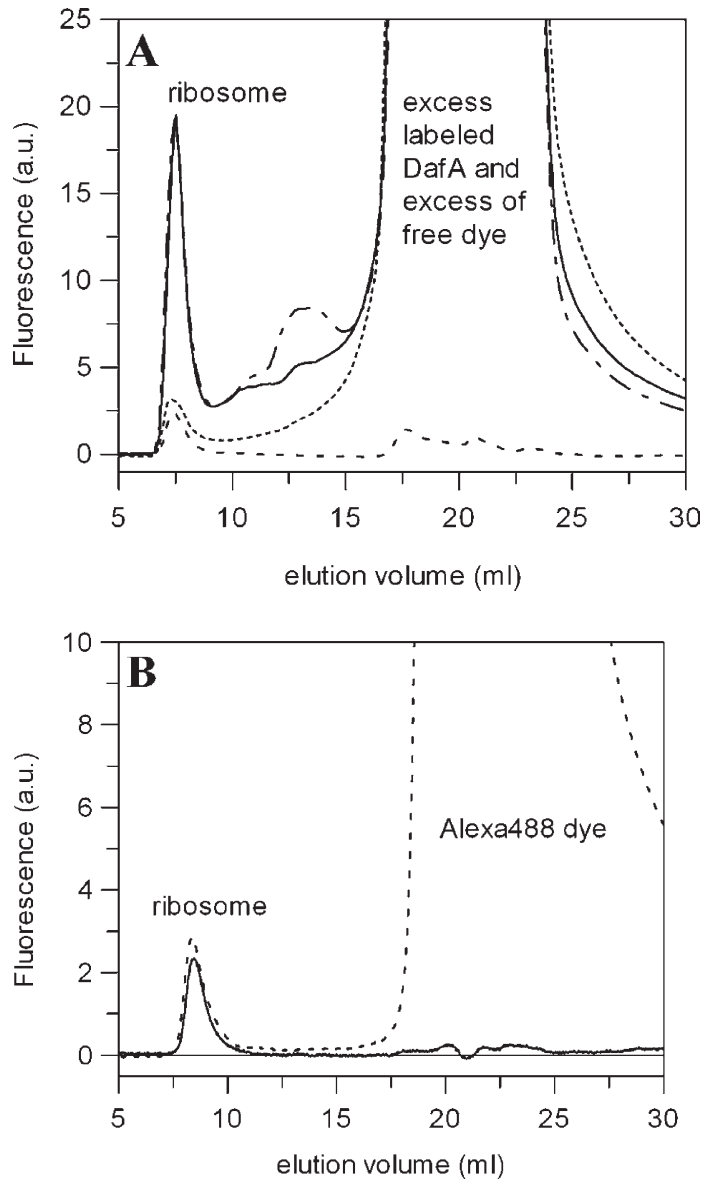

Figure 4. Interaction of $\mathrm{DafA}_{\mathrm{Tth}}-\mathrm{S} 14 \mathrm{C}-\mathrm{Alexa} 488$ with T. thermophilus $70 \mathrm{~S}$ ribosomes assayed by analytical gel filtration. (A) Binding of Alexa488-labeled DafA $\mathrm{Tth}_{\text {th }}-\mathrm{S} 14 \mathrm{C}$ to the ribosomes and its displacement by an excess of unlabeled protein. Ribosomes $(1 \mu \mathrm{M})$ (large dots) were incubated with $5 \mu \mathrm{M}$ labeled protein for 15 minutes at $30{ }^{\circ} \mathrm{C}$ in the absence (continuous line) or in the presence (small dots) of a tenfold excess of unlabeled protein. The influence of large RNA impurities present in the samples was analyzed by incubation of the ribosomes with DafA $\mathrm{T}_{\mathrm{Tth}}-\mathrm{S} 14 \mathrm{C}-$ Alexa488 in the presence of RNaseA (dashed-dot). The samples were briefly centrifuged and then applied to a Superdex S-200 analytical gel filtration column at a flow rate of $0.75 \mathrm{ml} /$ minute. (B) Incubation of ribosomes with an excess of Alexa488 dye. $70 \mathrm{~S}$ ribosomes $(0.5 \mu \mathrm{M})$ (continuous line) were incubated for 15 minutes at $30{ }^{\circ} \mathrm{C}$ with 50 -fold excess Alexa488-maleimide (dotted line) and subjected to analytical gel filtration on a Superdex S-200 at a flow rate of $0.5 \mathrm{ml} /$ minute.

between $\mathrm{DafA}_{\mathrm{Tth}}$ and the $70 \mathrm{~S}$ ribosomes we performed gel filtration experiments using the Alexa488-labeled DafA $\mathrm{Ath}_{\text {Th }}-\mathrm{S} 14 \mathrm{C}$ mutant. Due to their very high molecular mass, ribosomes are not separated on a Superdex S-200 gel filtration column, but are found in the exclusion volume instead. During these experiments, the DafA $\mathrm{A}_{\text {Th }}-$ ribosome complex formation was monitored via fluorescence emission of the ribosomal peak in the absence or presence of DafA $\mathrm{T}_{\mathrm{Tth}}-\mathrm{S} 14 \mathrm{C}$-Alexa488.

Figure 4(A) shows the characteristic elution profiles for such an experiment. The first peak 
corresponds to $70 \mathrm{~S}$ ribosomes and a $70 \mathrm{~S}$ ribosome-DafA $\mathrm{A}_{\mathrm{Tth}}$ complex and appears roughly at an elution volume of $8 \mathrm{ml}$. Interestingly, a fluorescence signal at this elution volume was also detected for a ribosome-only sample (large dots). The reason for this is not an intrinsic fluorescence of the ribosomes but the occurrence of light scattering due to the enormous size of these molecules. The addition of a fivefold excess of Daf $\mathrm{A}_{\mathrm{Tth}}-$ S14C-Alexa488 over the ribosome and incubation for 15 minutes at $30^{\circ} \mathrm{C}$ leads to an almost eightfold increase in the fluorescence emission of the ribosomes, which is an indication of complex formation (continuous line). The specificity of this interaction was probed by incubation of the two components in the presence of a tenfold excess of unlabeled DafA $\mathrm{Tth}_{\text {th }}$ over the concentration of the labeled protein (small dots). Under these conditions the amplitude of the fluorescent signal of the ribosome-Daf $\mathrm{A}_{\mathrm{Tth}}$ complex is decreasing drastically, being close to the one of ribosome-only sample. Using excess of ribosomes here would have been desirable but was not possible due to technical limitations, e.g. achieving the necessary ribosome concentration.

Despite the fact that the RNA-binding properties of Daf $A_{T t h}$ have not been clarified yet, we had to take into account the possibility that residual RNA in the ribosomal stock solution may lead to artifacts. Therefore, it was necessary to test whether the fluorescence of the ribosomal peak is not caused by an interaction between DafA $_{\text {Tth }}$ and some contaminating RNAs. However, this is not the case (Figure $4(\mathrm{~A})$, dash-dotted line ) since the presence of RNaseA during incubation of Daf $A_{T t h}$ with $70 \mathrm{~S}$ ribosomes does not reduce the fluorescence of the DafA $\mathrm{Ath}_{\text {Th }}$-ribosome complex.

It was noticed that an intense and broad peak appears at higher retention times. This corresponds to the excess of labeled protein and also to some residual Alexa488 dye which could not be completely removed during ultrafiltration. By incubating the $70 \mathrm{~S}$ ribosomes with a 50-fold excess of Alexa488 dye under the same conditions we could exclude that the increase in ribosome fluorescence in the presence of labeled DafA $\mathrm{T}_{\mathrm{Tth}}-\mathrm{S} 14 \mathrm{C}$ is caused by an unspecific interaction between the ribosomes and the free dye. As seen in Figure 4(B) there is no significant shift of the ribosome fluorescence even in the presence of such excess of dye. Thus, the higher fluorescence signal obtained in the presence of $\mathrm{DafA}_{\mathrm{Tth}}-\mathrm{S} 14 \mathrm{C}-\mathrm{Alexa} 488$ derives from complex formation between the two components and not from unspecific binding of the free dye.

\section{The DnaK Tth $_{\text {Tha }}-$ Dnth $_{\text {Th }}-$ DafA $_{\text {Tth }}$ complex is found in equilibrium with the ribosome-Daf $A_{T t h}$ complex in vitro}

Both sucrose cushion and gel filtration experiments demonstrate that $\operatorname{DafA}_{\text {Th }}$ is able to interact with T.thermophilus $70 \mathrm{~S}$ ribosomes in vitro. Furthermore, the formation of $\mathrm{DnaK}_{\mathrm{Tth}}-\mathrm{DnaJ}_{\mathrm{Tth}}-$
DafA $_{\text {Tth }}$ complex can be visualized by analytical gel filtration similar to ribosome-DafA ${ }_{T \text { th }}$ complexes when the labeled cysteine-DafA ${ }_{\text {Tth }}$ mutant is used. Taking advantage of this we tested whether DafA $\mathrm{Tth}_{\text {th }}$ is recruiting DnaK $\mathrm{Tth}_{\mathrm{T}}$ and DnaJ $\mathrm{Tth}_{\mathrm{Tth}}$ to the $70 \mathrm{~S}$ ribosomes. Figure 5 shows that $\mathrm{DafA}_{\mathrm{Tth}}$ does not mediate association of $\mathrm{DnaK}_{\mathrm{Tth}}-\mathrm{DnaJ}_{\mathrm{Tth}}$ and ribosomes. In contrast, the formation of the two complexes rather represents a competitive process in vitro. With a Superdex S-200 gel filtration column the two complexes are very well distinguished (Figure 5(A) and (B)). The ribosomeDafA $_{\text {Tth }}-\mathrm{S} 14 \mathrm{C}$-Alexa complex, with its high molecular mass, appears at $8 \mathrm{ml}$ elution volume followed by the DnaK $\mathrm{Tth}-\mathrm{DnaJ}_{\mathrm{T} \text { th }}-\mathrm{DafA}_{\mathrm{Tth}}-\mathrm{S} 14 \mathrm{C}-$ Alexa complex at $11 \mathrm{ml}$. Addition of $\mathrm{DnaK}_{\mathrm{Tth}}$ and DnaJ $_{\text {Tth }}$ to preformed ribosome-DafA Tth $-S 14 C-$ Alexa complexes leads to a significant fluorescence decrease in the ribosome-DafA $A_{\text {th }}$ peak (Figure 5(A)). The outcome of the reverse experiment (the addition of ribosomes subsequent to the formation of DnaK $_{\text {Tth }}-$ DnaJ $_{\text {Tth }}-$ DafA $_{\text {Tth }}-\mathrm{S} 14 \mathrm{C}-$ Alexa complex) is similar (Figure 5(B)). This time the fluorescence of $\mathrm{DnaK}_{\mathrm{Tth}}-\mathrm{DnaJ}_{\mathrm{Tth}}-\mathrm{DafA}_{\mathrm{Tth}}-$ S14C-Alexa decreases in favor of the ribosomeDafA $_{\text {Tth }}-S 14 C$-Alexa complex. These results clearly show that DafA ${ }_{\text {Tth }}$ can be exchanged between DnaK $\mathrm{Tth}_{\text {Th }}$ and $\mathrm{DnaJ}_{\mathrm{Tth}}$ on one hand and ribosome on the other hand.

A similar result was obtained in a sucrose cushion experiment (Figure 5(C)). Here, the concentration of the components was slightly modified to ensure that Daf $_{\text {Tth }}-\mathrm{S} 14 \mathrm{C}-\mathrm{Alexa}$ was still detectable even after inevitable loss of protein during experimental manipulation. We observed that the addition of $\mathrm{DnaK}_{\mathrm{Tth}}$ and $\mathrm{DnaJ}_{\mathrm{Tth}}$ to the already formed ribosome-DafA $\mathrm{T}_{\text {th }}-\mathrm{S} 14 \mathrm{C}-\mathrm{Alexa}$ complex (lanes 7 and 8) reduces slightly the ribosomal pellet fluorescence (lane 8) when compared to the same fraction of ribosome-DafA $\mathrm{T}_{\mathrm{Th}}-\mathrm{S} 14 \mathrm{C}-$ Alexa sample (lane 6). Similarly, upon addition of ribosomes to the preformed DnaK $_{\text {Tth }}-$ DnaJ $_{\text {Tth }}-$ DafA $_{\text {Tth }}-$ S14C-Alexa complex (lanes 9 and 10), a faint but visible band is detected in the ribosomal pellet (lane 10). It is important to note that only half of the samples were applied to SDS-PAGE and therefore resulted in a weak fluorescence signal observed in the pellets (corresponding only to $0.25 \mu \mathrm{M}$ ribosomes). Remarkably, the ribosomeDafA $_{\text {Tth }}-\mathrm{S} 14 \mathrm{C}$-Alexa complex is still formed even in the presence of a tenfold excess DnaK $\mathrm{Tth}_{\mathrm{T}}$ and DnaJ $_{\text {Tth }}$ over the ribosome concentration (Figure 5(C), lanes 8 and 10), indicating that the interaction of DafA $\mathrm{Tth}_{\mathrm{T}}$ with the ribosomes is significantly tighter than the interaction with $\mathrm{DnaK}_{\mathrm{Tth}}$ and DnaJ ${ }_{\text {Tth }}$.

The DnaK Tth - DnaJ $_{\text {Tth }}-$ DafA $_{\text {Tth }}$ complex is composed of three copies of each protein. Although determination of the stoichiometry of the ribosome-DafA $A_{\text {Tth }}$ complex is not straightforward, we can estimate that DafA $\mathrm{A}_{\mathrm{Tth}}$ binds the ribosome as a monomer rather than a trimer by comparing the fluorescence intensities of the $\mathrm{DnaK}_{\mathrm{Tth}}-\mathrm{DnaJ}_{\mathrm{Tth}}-$ 

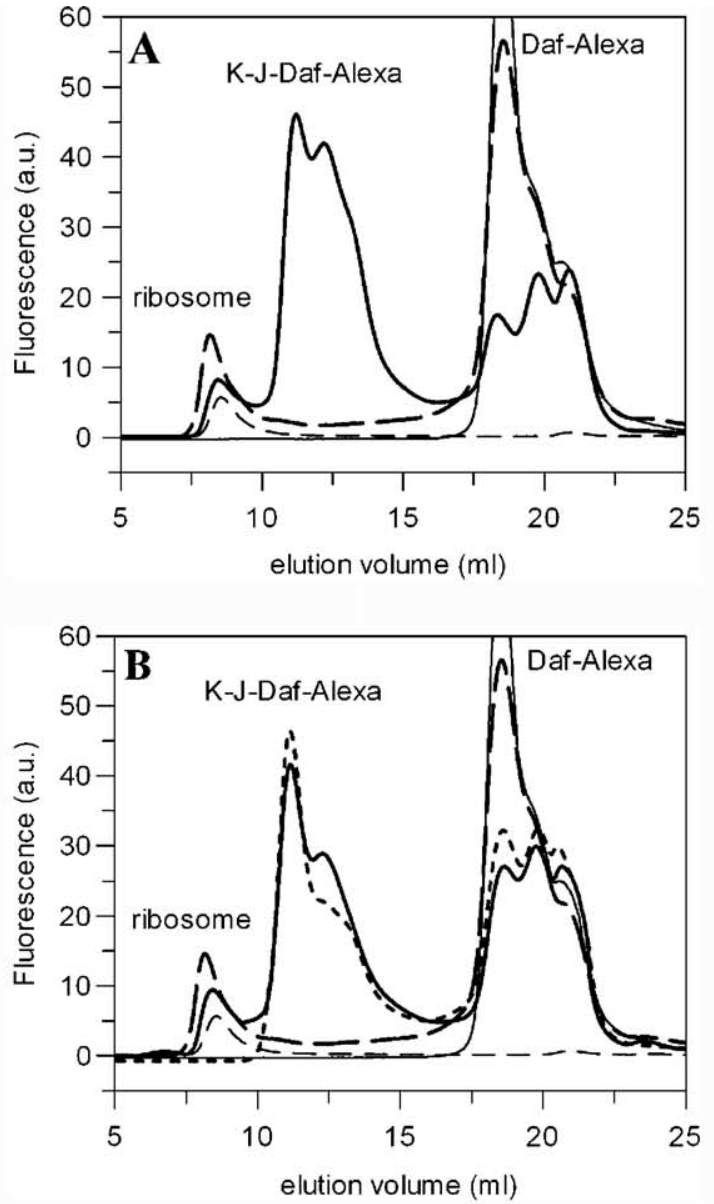

C

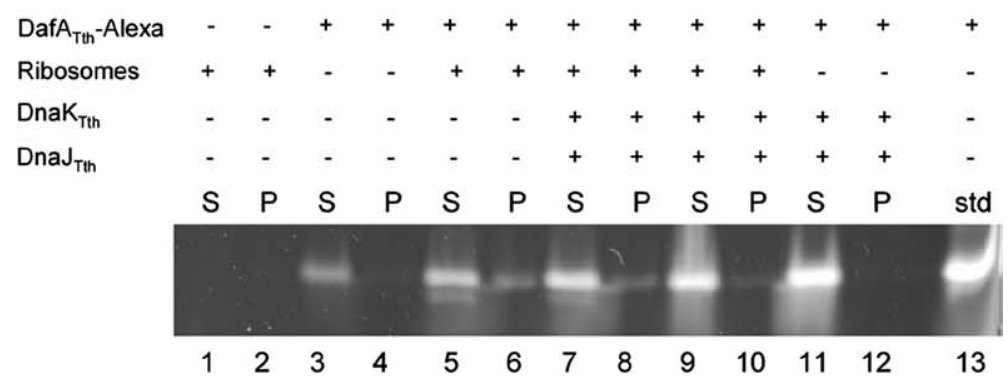

Figure 5. DnaK $\mathrm{Tth}_{\mathrm{Th}}$ and $\mathrm{DnaJ}_{\mathrm{Tth}}$ compete with $70 \mathrm{~S}$ ribosomes for DafA $_{\text {Tth }}-$ S14C-Alexa488 binding. (A) Recruitment of ribosomebound DafA $_{\text {Tth }}-\mathrm{S} 14 \mathrm{C}-$ Alexa488 by DnaK $_{\text {Tth }}$ and DnaJ ${ }_{\text {Tth }}$ in gel filtration assay. DafA $\mathrm{A}_{\mathrm{Tth}}-\mathrm{S} 14 \mathrm{C}-$ Alexa488 $(0.5 \mu \mathrm{M})$ was incubated with $1 \mu \mathrm{M}$ ribosomes at $37^{\circ} \mathrm{C}$ (broken line). After one hour incubation time DnaK $_{\text {Tth }}$ and DnaJ ${ }_{\text {Tth }}$ were added at a threefold excess over ribosome concentration and the mixture was re-incubated under the same conditions (continuous line). Ribosomes only (dotted thin line) and DafA $_{\text {Tth }}-$ S14C-Alexa488 only (continuous thin line) samples were treated accordingly and used as controls. (B) Recruitment of DafA $_{\text {Tth }}$-Alexa from DnaK Tth $^{-}$ DnaJ $_{\text {Tth }}-$ DafA $_{\text {Tth }}-$ Alexa complex by the $70 \mathrm{~S}$ ribosomes. DafA $\mathrm{A}_{\mathrm{Tth}}-\mathrm{S} 14 \mathrm{C}-$ Alexa488 $(0.5 \mu \mathrm{M})$ (continuous thin line) was incubated with equimolecular concentrations of $\mathrm{DnaK}_{\mathrm{Tth}}$ and DnaJ ${ }_{T \text { th }}$ (small dots, continuous line). After incubation of the three components for one hour at $37^{\circ} \mathrm{C}$ ribosomes were added to a final concentration of $1 \mu \mathrm{M}$ (continuous line). The resulting spectra were compared to samples containing ribosomes only (dotted thin line) and the ribosomes-DafA $\mathrm{Tth}_{\mathrm{Th}}-\mathrm{S} 14 \mathrm{C}-$ Alexa488 complex (broken line) samples. (C) Competition between DnaK $_{\text {Tth }}-$ DnaJ $_{\text {Tth }}$ and ribosomes for DafA $_{\text {Tth }}-S 14 C$-Alexa488 binding in sucrose cushion assay. DafA $\mathrm{Ath}_{\text {Th }}-$ S14C-Alexa488 at a concentration of $2 \mu \mathrm{M}$ was incubated with $0.5 \mu \mathrm{M} 70 \mathrm{~S}$ ribosomes (lanes 5 and 6). After one hour at $30^{\circ} \mathrm{C}, 5 \mu \mathrm{M}$ DnaK $_{\text {Tth }}$ and $5 \mu \mathrm{M}$ DnaJ ${ }_{\text {Tth }}$ were added and the sample was incubated for another hour (lanes 7 and 8 ). In lanes 9 and 10, the order of addition was inverted (first DnaK $\mathrm{T}_{\mathrm{Tth}}$

and DnaJ $\mathrm{Tth}_{\mathrm{Th}}$ then the ribosomes). The control samples are represented by ribosome-only (lanes 1 and 2 ), DafA $\mathrm{A}_{\mathrm{Tth}}-$ S14C-Alexa488 only (lanes 3 and 4), the DnaK Tth $_{-}-$DnaJ $_{\text {Th }}-$ DafA $_{\text {Th }}-S 14 C-$ Alexa488 complex (lanes 11 and 12 ) and a DafA $_{T \text { th }}-\mathrm{S} 14 \mathrm{C}-\mathrm{Alexa} 488$ sample, which was not subjected to sucrose cushion as standard (std, lane 13). Before electrophoresis samples were TCA-precipitated.

DafA $_{\text {Tth }}-\mathrm{S} 14 \mathrm{C}-\mathrm{Alexa}$ and ribosome-DafA $\mathrm{Tth}_{\mathrm{T}}-$ S14C-Alexa complexes. This estimation assumes, however, that the fluorescence intensities of DafA $_{\text {Tth }}$ in both complexes are comparable.

\section{Discussion}

\section{DnaK $_{T \text { th }}-$ Dna $_{\text {Tth }}-$ DafA $_{\text {Tth }}$ complex is unable to assist protein folding}

Competition experiments using fluorescent peptides showed that, in the presence of DnaJ ${ }_{T \text { th }}$
DafA $_{\text {Tth }}$ interferes with peptide binding to DnaK $_{\text {Tth }} \cdot{ }^{11}$ On the basis of this finding, a model for the regulation of the DnaK $\mathrm{T}_{\mathrm{Tth}}$ chaperone cycle was proposed. ${ }^{11}$ This model suggests that there are two separate states of the DnaK $\mathrm{Tth}_{\text {th }}$ system: a DnaK ${ }_{3}$ DnaJ $_{3}-$ DafA $_{3}$ complex representing the resting state and DnaK $_{3}$-substrate-DnaJ ${ }_{3}$ complex as active chaperone species. According to the model the transition to the active state is determined by the critical concentration of denatured proteins as a consequence of stress conditions (e.g. heat shock) and results in the displacement of DafA $\mathrm{A}_{\text {th }}$ by substrate. Rebinding of ATP under $\mathrm{GrpE}_{\mathrm{Tth}}$ 's 
control allows the release of the substrate. This cycle of substrate binding and release may continue for several rounds or the complex returns to the resting state by rebinding of DafA $\mathrm{T}_{\text {Th }}$ ("switching off").

The incompatibility between the binding of peptide substrates and the presence of DafA $\mathrm{A}_{\mathrm{Tth}}$ within the complex led to the assumption that DnaK $\mathrm{T}_{\mathrm{Th}}-$ DnaJ $_{\text {Tth }}-$ DafA $_{\text {Tth }}$ cannot represent the active form of the complex. Data presented here support this hypothesis. Here, instead of small peptides a real protein substrate, luciferase $\mathrm{e}^{20,21}$ was used. The refolding of $\mathrm{GdnHCl}$-denatured luciferase can be monitored on-line in a continuous assay where DnaK $_{\text {Tth }}$ and its co-chaperones are added in a defined ratio. ${ }^{15}$ The presence of an excess of DafA $_{\text {Tth }}$ within this refolding mixture has a strong inhibitory effect on luciferase renaturation (Figure 2) independent on the moment of DafA $\mathrm{Tth}_{\mathrm{Tth}}$ 's addition.

These data corroborate the competitive mechanism of the binding of DafA $A_{\text {Th }}$ and substrates to a DnaK $_{\text {Tth }}-$ DnaJ $_{\text {Tth }}$ complex and thus prove that the DnaK $_{\text {Tth }}-$ DnaJ $_{\text {Tth }}-$ DafA $_{\text {Tth }}$ complex cannot be the active form of the refolding machinery.

\section{Daf $A_{T t h}$ is not implicated in the transcriptional regulation of the DnaK $_{\mathrm{Tth}}$ operon}

The predicted helix-loop-helix secondary structure and DNA/RNA-binding protein fold, the homology with the transcriptional regulator HspR from S. coelicolor and the co-elution with RNA during purification, indicate a regulatory function of DafA $\mathrm{T}_{\text {Th }}$ on the DNA/RNA level that might be connected to the heat shock response. This function could be directed to its own operon or to other important cellular sites possibly involved in the proposed regulatory role.

The DnaK operon from T. thermophilus is preceded by a single promotor region, which is homologous to E. coli consensus promotor sequences. ${ }^{22}$ Thus, this sequence could be recognized by the $\sigma^{32}$ transcription factor which is responsible for heat shock regulation in the cytoplasm of Gram-negative bacteria. ${ }^{23-26}$ Although the thermophilic homolog for E. coli $\sigma^{32}$ has not been identified yet, DnaK $\mathrm{Tth}_{\mathrm{T}}$ is nevertheless able to form complexes with a peptide derived from E. coli $\sigma^{32}$. Hence, it is conceivable that the transcriptional regulation of the heat shock response in T. thermophilus is based on a mechanism that resembles the one from E. coli to some extent.

Supposing that free DafA $_{\text {Tth }}$ may interfere with $\sigma^{32}$ binding to regulatory regions found in the $\mathrm{DnaK}_{\text {Tth }}$ promotor, we carried out binding experiments that involved DafA $\mathrm{D}_{\mathrm{T}}$ and DNA segments containing the -35 and -10 cassettes. The results obtained showed that Daf $_{\text {Tth }}$ does not recognize these regulating elements in vitro (data not shown). Thus, we could not confirm a regulatory mechanism of DnaK $\mathrm{T}_{\mathrm{T} \text { th }}$ gene expression involving DafA $_{\text {Tth }}$ as a suppressor of $\sigma^{32}$ action.
Similar analyses were carried out with the transcriptional repressor HspR from S. coelicolor. The primary sequence of HspR exhibits some homology ( $21 \%$ identity) to the one of DafA $\mathrm{Ath}_{\mathrm{Tth}}$. Furthermore, the organization of the DnaK operon in T. thermophilus is similar to the one from S. coelicolor. Within this organization, $\operatorname{DafA}_{\mathrm{Tth}}$ occupies the same position as HspR in the sequence dnaK-grpEdnaJ-orfX, orfX gene corresponding to DafA/ HspR. In S. coelicolor HspR acts as a repressor of the DnaK operon gene expression by binding to several inverted repeat sequences (IRs) in the promotor region. ${ }^{27-29}$ Assuming that Daf $_{\text {Tth }}$ and HspR could be functional homologs despite the relatively low amino acid identity, we performed various binding experiments to check whether DafA $_{\text {Tth }}$ interacts with the IRs identified in the thermophilic DnaK promotor. The experiments, however, did not provide evidence that DafA $_{T \text { th }}$ recognizes these DNA sequences in vitro (data not shown).

To conclude, there is no indication that the potential regulatory function of free DafA $_{T \text { th }}$ is pointed towards the $\mathrm{DnaK}_{\mathrm{Tth}}$ operon in terms of transcriptional regulation of gene expression.

\section{The DafA $A_{\text {Th }}$-ribosome complex and its relationship with DnaK $_{T \text { th }}-$ DnaJ $_{T \text { th }}-$ DafA $_{T \text { th }}$}

Since a potential regulatory function at the transcriptional level could not be revealed and yet some RNA-binding was observed, the search for potential interaction partners of DafA $_{\text {Th }}$ has brought our attention to the translational machinery. The complex formation between DafA $\mathrm{A}_{\mathrm{Tth}}$ and isolated T. thermophilus $70 \mathrm{~S}$ ribosomes was analyzed via various in vitro approaches, considering the specific features of the ribosomes. Sucrose cushion assays offer clear evidence of a binding event occurring between the two molecules, regardless of the DafA $A_{\text {Tth }}$ variant used $\left(\right.$ Daf $_{\text {Tth }}$ or Alexa488-labeled DafA $\mathrm{Tth}_{\mathrm{Tth}}-\mathrm{S} 14 \mathrm{C}$ mutant). Furthermore, gel filtration experiments carried out with the labeled DafA $\mathrm{T}_{\mathrm{Th}}-\mathrm{S} 14 \mathrm{C}$ variant supported the results obtained by the sucrose cushion assay. The increase in fluorescence signal of the $70 \mathrm{~S}$ ribosomes in the presence of DafA $\mathrm{T}_{\text {Th }}-\mathrm{S} 14 \mathrm{C}-\mathrm{Alexa} 488$ clearly indicates that a ribosome-Daf $\mathrm{A}_{\mathrm{Tth}}$ complex is formed. Competition experiments showed that the assembly of this complex is a specific process, excess of unlabeled Daf $A_{\text {Tth }}$ being able to reduce the fluorescence signal to a value close to the one of the ribosome-free DafA $_{\text {Th }}-\mathrm{S} 14 \mathrm{C}$-Alexa488. Hence, we conclude that DafA $A_{T \text { th }}$ is a novel ribosome-associated molecular chaperone when released from the DnaK $\mathrm{Tth}_{\mathrm{Th}}-\mathrm{DnaJ}_{\mathrm{Tth}}-\mathrm{DafA}_{\mathrm{Tth}}$ complex.

The presence of ribosome-associated chaperones was revealed in both prokaryotic and lower eukaryotic model systems. ${ }^{30,31}$ The E.coli trigger factor (TF) and Ssb from Sacharomyces cerevisiae are the best studied ribosome-bound chaperones. Although both have chaperone activity while bound to the ribosomes, TF and Ssb do not share 

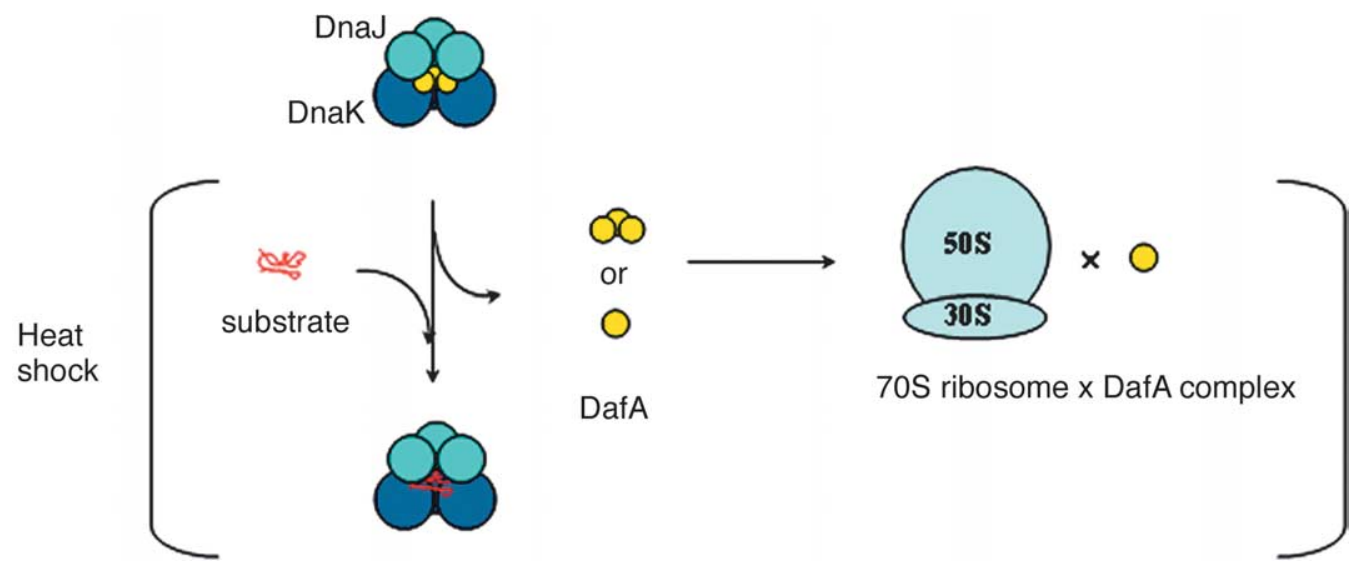

Figure 6. Schematic representation of Daf $\mathrm{A}_{\text {Tth }}$ pathway during heat shock conditions. During heat shock conditions DafA $_{\text {Tth }}$ must be replaced from the complex by the denatured proteins. Since DafA $A_{\text {Tth }}$ is not a part of the active chaperone system it might have regulatory functions connected to the heat shock response after its release from the complex. The complex formed between Daf $\mathrm{A}_{\text {Tth }}$ and the $70 \mathrm{~S}$ ribosomes reconstructed in vitro indicates that monomeric $\operatorname{DafA}_{\mathrm{Tth}}$ is targeted to the translational machinery. The assembly strongly suggests that DafA $\mathrm{T}_{\mathrm{Tth}}$ may act as a regulatory factor at the translational level. Though DafA $\mathrm{T}_{\text {th }}$ shows limited RNA-binding properties, the contribution of RNA molecules (tRNA, mRNA) to the regulatory events is not yet clear.

sequence similarity. TF belongs to the peptidylprolyl-cis-trans isomerase (PPIase) family, $32-34$ whereas Ssb is a member of the Hsp70 family. TF is thought to function as a monomer on ribosomes $^{35}$ and it was demonstrated that it cooperates with DnaK in folding of newly synthesized proteins. ${ }^{36,37}$ The function of Ssb requires two additional proteins: Zuotin, a DnaJ-like chaperone, ${ }^{38}$ and Ssz, another Hsp70 family member. All three assemble into a "ribosome-associated complex" (RAC) that also functions on the ribosome. ${ }^{39,40}$

In relationship with these findings we addressed the question whether DafA $A_{T t h}$ recruits DnaK $\mathrm{K}_{\mathrm{Tth}}$ and $\mathrm{DnaJ}_{\mathrm{Tth}}$ to the ribosome. Both gel filtration and the sucrose cushion assay results show that the DnaK $_{\text {Tth }}-$ DnaJ $_{\text {Tth }}-$ DafA $_{\text {Tth }}$ complex does not associate with the ribosome. On the contrary, assembly of these two complexes seems to be a competitive process, Daf $\mathrm{A}_{\text {Tth }}$ being shuttled between ribosomes and $\mathrm{DnaK}_{\mathrm{Tth}}-\mathrm{DnaJ}_{\mathrm{Tth}}$. From the protein folding point of view, this finding is not too surprising considering that the DnaK $\mathrm{Tth}_{\mathrm{Th}}-\mathrm{DnaJ}_{\mathrm{Tth}}-\mathrm{DafA}_{\mathrm{Tth}}$ complex is unable to assist protein folding.

We hypothesize that shuttling of DafA $\mathrm{Ath}_{\text {Th }}$ between the two complexes has a regulatory meaning within the framework of a heat shock response. The complete understanding of how the T. thermophilus DnaK chaperone system is regulated requires a more detailed understanding of DafA $_{\text {Tth }}$-ribosome interaction. In this respect, identification of a DafA $\mathrm{ATth}_{\mathrm{Th}}$ docking site on the ribosome might be one of the first steps necessary. Competition experiments using $\mathrm{TF}_{\mathrm{Tth}}$ have shown that DafA $\mathrm{Tth}_{\mathrm{Th}}$ and $\mathrm{TF}_{\mathrm{Tth}}$ do not share the same binding site on the ribosome (data not shown). Since the ribosomal-binding site of TF is found close to the exit tunnel of newly synthesized polypeptides, ${ }^{41,42}$ a different location of Daf $\mathrm{A}_{\text {Tth }}$ indi- cates once more that DafA $\mathrm{A}_{\text {Tth }}$ is most likely not involved in co-translational protein folding. The RNA-binding capacity of DafA $\mathrm{A}_{\text {Th }}$ suggests that binding to the ribosome could mainly be mediated by rRNA or rRNA with ribosomal proteins rather than ribosomal proteins only.

Although in vivo studies might drastically increase the knowledge about functional aspects of the ribosome-DafA $A_{\text {Tth }}$ interaction in respect to the heat shock response, this approach is not feasible at present, due to difficulties in genetic manipulation of T. thermophilus strains. On the other hand, our attempt to identify Daf $\mathrm{A}_{\mathrm{Tth}}$ in T. thermophilus lyzates at various incubation temperatures including heat shock conditions was unsuccessful, suggesting a very low abundance of DafA $_{\text {Tth }}$ in the cell.

To summarize, the results presented here clearly show that DafA $A_{\text {Tth }}$ has to be removed from the DnaK $_{\text {Thh }}-$ DnaJ $_{\text {Tth }}-$ DafA $_{\text {Tth }}$ complex by the substrate proteins to allow for chaperone-assisted protein refolding and that free DafA $_{\text {Tth }}$ can associate specifically with the $T$. thermophilus $70 \mathrm{~S}$ ribosomes (Figure 6), which strongly suggests a regulatory role within the framework of the heat shock regulation.

\section{Materials and Methods}

\section{Protein expression and purification}

Wild-type DnaK $\mathrm{Tth}_{\text {th }}$ and DnaJ $\mathrm{Tth}_{\mathrm{T}}$ were expressed and purified as described. ${ }^{11,19}$ Wild-type Daf $\mathrm{A}_{\text {Tth }}$ is not stably produced in E. coli because of its N-terminal leucine residue (N-end rule in bacteria ${ }^{43}$ ). Instead, the point mutant $\operatorname{DafA}_{\text {Tth }}(\mathrm{L} 2 \mathrm{~V})$ was used ${ }^{11}$ and is abbreviated as DafA $\mathrm{A}_{\text {Th }}$ from here on. The following changes were made to the original protocol: for induction of $\mathrm{DafA}_{\mathrm{Tth}}$ overproduction, IPTG was added to a final concentration of $0.5 \mathrm{mM}$ 
and the induced cells were grown overnight at $28^{\circ} \mathrm{C}$. The extraction of $\mathrm{DafA}_{\mathrm{Tth}}$ from the inclusion bodies was improved by increasing the urea concentration to $4 \mathrm{M}$. After the initial gel filtration step, a strong anion exchanger (MonoQ, Amersham-Pharmacia, Uppsala, Sweden) was used to remove contaminating nucleic acids from the protein solution. In a buffer containing $4 \mathrm{M}$ urea, DafA $\mathrm{T}_{\text {Th }}$ does not bind to the MonoQ column and it is found in the flowthrough. Interestingly, in the absence of urea $\operatorname{DafA}_{\mathrm{Tth}}$ is bound very tightly to the column and elutes at about $0.9 \mathrm{M} \mathrm{KCl}$ (data not shown). DafA $_{T \text { th }}$ fractions were pooled and dialyzed against storage buffer $(20 \mathrm{mM}$ Hepes $/ \mathrm{NaOH}$ ( $\mathrm{pH} 7.5), 50 \mathrm{mM}$ $\mathrm{KCl}, 1 \mathrm{mM} \mathrm{MgCl} 2,10 \%$ (v/v) glycerol). Following this protocol, a yield of more than $4 \mathrm{mg} / \mathrm{l}$ of cell culture with more than $99 \%$ purity as judged by SDS-PAGE was obtained.

\section{Site-directed mutagenesis and labeling of DafL2V-S14C with Alexa 488-maleimide}

The mutant DafA $_{\text {Tth }}-\mathrm{S} 14 \mathrm{C}$ was engineered by sitedirected mutagenesis with the QuickChange kit of Stratagene (La Jolla, USA). It was purified as described above, but under reducing conditions (all buffers contain 5 mM DTE).

The labeling of DafA $_{T \text { Th }}-\mathrm{S} 14 \mathrm{C}$ with Alexa 488-maleimide (Molecular Probes, Eugene, USA) was carried out conform to the manufacturer's recommendations in labeling buffer (50 mM Hepes/ $\mathrm{NaOH}$ (pH 7.5), $150 \mathrm{mM}$ $\mathrm{KCl}, 5 \mathrm{mM} \mathrm{MgCl}$, $2 \mathrm{mM}$ EDTA, $2 \mathrm{mM}$ sodium ascorbate, $4 \mathrm{M}$ urea, $10 \%$ glycerol). After overnight incubation at $4{ }^{\circ} \mathrm{C}$, excess dye was removed by ultrafiltration in an Amicon chamber (Amicon, Beverly, USA) using a $3 \mathrm{kDa}$ cut off membrane. This washing step was carried out with the labeling buffer supplemented with $5 \mathrm{mM}$ DTE. The presence of $4 \mathrm{M}$ urea in the washing buffer is necessary to prevent aggregation of the labeled protein during ultrafitration. A NAP-5 desalting column (Amersham Bioscience, Uppsala, Sweden) was used to remove urea from the sample. The labeled protein was stored in a buffer containing $20 \mathrm{mM}$ Hepes/NaOH (pH 7.5), $100 \mathrm{mM} \mathrm{KCl}$, $2 \mathrm{mM} \mathrm{MgCl}, 5 \mathrm{mM}$ DTE and 10\% glycerol. The concentration of $\mathrm{DafA}_{\mathrm{Tth}}-\mathrm{S} 14 \mathrm{C}-\mathrm{Alexa} 488$ was calculated from the absorption at $280 \mathrm{~nm}\left(\varepsilon=15,220 \mathrm{M}^{-1} \mathrm{~cm}^{-1}\right)$ after subtraction of the dye's contribution. Labeling efficiency was calculated using the following equation:

$$
\begin{aligned}
& A_{\mathrm{x}} / \varepsilon \times M_{\mathrm{r}} \text { of protein } / \mathrm{mg} / \mathrm{ml} \\
& \quad=\text { moles of dye } / \text { moles of protein }
\end{aligned}
$$

where $A_{\mathrm{x}}$ is the absorbance value of the dye at the absorption maximum wavelength, $\varepsilon$ is molar extinction coefficient of the dye at the absorption maximum wavelength. The efficiency of labeling was $\geq 60 \%$.

\section{Luciferase refolding in a continuous assay}

The assay was essentially performed as described. ${ }^{15}$ Luciferase (Promega, Madison, USA) was incubated for two minutes in unfolding buffer $(25 \mathrm{mM}$ Hepes/NaOH (pH 7.5), $50 \mathrm{mM} \mathrm{KCl}, 15 \mathrm{mM} \mathrm{MgCl} 2,2 \mathrm{mM}$ DTE, $1 \mathrm{mM}$ ATP, $0.05 \mathrm{mg} / \mathrm{ml}$ acetylated BSA, $5 \mathrm{M} \mathrm{GdnHCl}$ ) and subsequently diluted 125 -fold into refolding/assay buffer with $240 \mu \mathrm{M}$ CoA and $0.1 \mathrm{mM}$ luciferin. The refolding was measured continuously at $30^{\circ} \mathrm{C}$ using an Ascent Fluoroskan Fl spectrometer (Labsystems, Helsinki, Finland). The concentrations of chaperones contained in the refolding buffer were: $3.2 \mu \mathrm{M}$ DnaK, $0.4 \mu \mathrm{M}$ GrpE,
1.6 $\mu \mathrm{M}$ DnaJ, $0.08 \mu \mathrm{M}$ luciferase. DafA $\mathrm{T}_{\text {Th }}(2 \mu \mathrm{M})$ was added at various time points during the refolding assay.

\section{Purification of $70 \mathrm{~S}$ ribosomes from Thermus thermophilus}

T. thermophilus strain HB27 (ATCC BAA-163) was grown at $70{ }^{\circ} \mathrm{C}$ under strong aeration in a medium containing $4 \mathrm{~g}$ Peptone-140, $2 \mathrm{~g}$ yeast extract and $1 \mathrm{~g}$ of $\mathrm{NaCl}$ per liter supplemented with Castenholz salts $(\mathrm{pH}$ 7.5). ${ }^{44}$ Cells were harvested and stored at $-80^{\circ} \mathrm{C}$ until use. All buffers used were at $4{ }^{\circ} \mathrm{C}$ and contained $6 \mathrm{mM}$ 2-mercaptoethanol unless indicated otherwise. The frozen cells were disrupted by grinding with twice the cell mass of alumina (Sigma-Aldrich, MO, USA) and then resuspended in $20 \mathrm{mM}$ Hepes/NaOH $(\mathrm{pH}$ 7.5), $10.5 \mathrm{mM} \mathrm{MgCl}_{2}, 60 \mathrm{mM} \mathrm{NH}_{4} \mathrm{Cl}, 0.5 \mathrm{mM}$ EDTA, $0.1 \mathrm{mM}$ PMSF. Alumina and cell debris were removed by centrifugation (30 minutes at $16,000 \mathrm{~g}$ (Sorvall SLA-600TC rotor); twice for 15 minutes at 20,000g (Beckman Ti45 rotor)). The supernatant was applied onto at least an equal volume of a cushion containing $20 \mathrm{mM}$ Hepes/ $\mathrm{NaOH}(\mathrm{pH} 7.5), 1 \mathrm{M} \mathrm{NH}_{4} \mathrm{Cl}, 1.1 \mathrm{M}$ sucrose, $10.5 \mathrm{mM}$ $\mathrm{MgCl}_{2}, 0.5 \mathrm{mM} \mathrm{EDTA}^{45}$ and centrifuged at $148,000 \mathrm{~g}$ (Beckman Ti60 rotor) for 15 hours. The pellet containing salt-washed $70 \mathrm{~S}$ ribosomes was briefly washed with ribosomal storage buffer $(20 \mathrm{mM}$ Hepes $/ \mathrm{NaOH}(\mathrm{pH} 7.5)$, $50 \mathrm{mM} \mathrm{KCl}, 100 \mathrm{mM} \mathrm{NH} \mathrm{Nl}_{4}, 10.5 \mathrm{mM} \mathrm{MgCl}, 0.5 \mathrm{mM}$ EDTA) and then resuspended in the same buffer. The ribosome solution was further clarified from eventual aggregates by 30 minutes centrifugation at $20,000 \mathrm{~g}$ (Beckman Ti45 rotor) and then three hours at 148,000g (Beckman Ti60 rotor). The pellet was washed again and resuspended in a low volume of ribosomal storage buffer. The concentration of high salt washed $70 \mathrm{~S}$ ribosomes was calculated with the equation: $1 A_{260}=25$ pmol ribosome.

\section{Sucrose cushion assay}

DafA $_{\text {Tth }}$ or DafA Tth $_{\text {th }}-\mathrm{S} 14 \mathrm{C}-\mathrm{Alexa} 488$ mutant were incubated with the T. thermophilus ribosomes for the indicated times and temperatures in the ribosome interaction buffer (20 mM Hepes/NaOH (pH 7.5), $60 \mathrm{mM} \mathrm{KCl,}$ $10 \mathrm{mM} \mathrm{MgCl} 2,4 \mathrm{mM}$ 2-mercaptoethanol, 10\% glycerol). The mixture was then layered onto a twofold volume of $30 \%(\mathrm{w} / \mathrm{v})$ sucrose in the interaction buffer and centrifuged at $4{ }^{\circ} \mathrm{C}$ for 70 minutes at 75,000 rpm $(\sim 80,000 \mathrm{~g})$ in a TLA-100 rotor (Beckman, CA, USA). The supernatants were collected and the ribosomal pellets were briefly washed. Except for the experiment presented in Figure 3(A), both the supernatants and the ribosomal pellets were TCA-precipitated before applying on $16.5 \%$ Tris-Tricine denaturing gels. ${ }^{46}$ Only half of the total sample volume was applied on the gel. The gels were then subjected to Western blotting using rabbit-anti $\operatorname{DafA}_{\text {Tth }}$ antibodies or to fluoroimaging in the case of fluorescent labeled DafA $A_{\text {Th }}$ using a FLA-5000 fluorescence scanner (Fuji Photo Film Co., Tokyo, Japan).

\section{Analytical gel filtration}

Analytical gel filtration experiments were carried out on a Superdex S-200 HR10/30 (Amersham Biosciences) column (optimal separation range: $10-600 \mathrm{kDa}$ ) using a high performance liquid chromatography system (Waters, Milford, USA). The column was connected inline with a scanning fluorescence detector. The excitation 
and emission wavelengths were $493 \mathrm{~nm}$ and $516 \mathrm{~nm}$, respectively. The samples were incubated for indicated times and temperatures in ribosome interaction buffer (see Sucrose cushion assay). The elution was carried out with a buffer containing $50 \mathrm{mM}$ Hepes/ $\mathrm{NaOH}(\mathrm{pH}$ 7.5), $100 \mathrm{mM} \mathrm{NaCl}, 12 \mathrm{mM} \mathrm{MgCl} 2,2 \mathrm{mM}$ EDTA and $4 \mathrm{mM} 2-$ mercaptoethanol at a flow rate of $0.5 \mathrm{ml} / \mathrm{minute}$ or $0.75 \mathrm{ml} /$ minute. Before applying on the column the samples were briefly centrifuged for removal of eventual aggregates.

\section{Nucleic acid analysis}

The nucleic acids present in Daf $\mathrm{A}_{\text {Tth }}$ samples were isolated by phenol/chloroform-extraction followed by ethanol-precipitation. The pellet containing nucleic acids was resuspended in DEPC-water. Digestions were carried out for one hour at $37^{\circ} \mathrm{C}$ by using $50 \mu \mathrm{g} / \mathrm{ml}$ DNaseI or RNaseA in $10 \mathrm{mM}$ Tris- $\mathrm{HCl}$ ( $\mathrm{pH}$ 7.5). To estimate roughly the molecular mass of the nucleic acids a 33mer RNA was used as marker.

\section{Electrophoresis and Western blotting (immunoblotting)}

Electrophoresis of DNA and RNA was performed by standard procedures using denaturing polyacrylamideurea gels. ${ }^{47}$ The proteins were separated on $16.5 \%(\mathrm{w} / \mathrm{v})$ Tris-Tricine denaturing gels and stained with Coomassie brilliant blue. For Western blotting the proteins were electrotransferred to a PVDF membrane (Bio-Rad Lab., CA, USA), blocked for one hour at room temperature in $1 \%$ blocking solution (Bio-Rad) diluted in TBS (50 mM Tris ( $\mathrm{pH} 7.5), 150 \mathrm{mM} \mathrm{NaCl}$ ), and incubated for one hour with polyclonal antibodies against $\mathrm{DafA}_{\text {Tth }}$ in $0.5 \%$ blocking solution-TBS. Membranes were washed with TBS-Tween (TBS containing $0.1 \%$ Tween-20), incubated with goat anti-rabbit IgG-horseradish peroxidase (Promega) for one hour, washed again, and then the bands were visualized by chemiluminescence (Roche, Basel, Switzerland). Native gels were prepared and used as described. ${ }^{11}$

\section{Acknowledgements}

This work was supported by a grant from the Deutsche Forschungsgemeinschaft to J.R. (RE 1212/1-1). We also thank Reinhard Hensel (Essen) for help with fermentation of T. thermophilus cells and are indebted to Roger S. Goody and Ilme Schlichting for continuous and generous support.

\section{References}

1. Liberek, K., Georgopoulos, C. \& Zylicz, M. (1988). Role of the Escherichia coli DnaK and DnaJ heat shock proteins in the initiation of bacteriophage lambda DNA replication. Proc. Natl Acad. Sci. USA, $85,6632-6636$.

2. Hartl, F. U. (1996). Molecular chaperones in cellular protein folding. Nature, 381, 571-579.

3. Bukau, B. \& Horwich, A. L. (1998). The Hsp70 and Hsp60 chaperone machines. Cell, 92, 351-366.

4. Bukau, B., Deuerling, E., Pfund, C. \& Craig, E. A.
(2000). Getting newly synthesized proteins into shape. Cell, 101, 119-122.

5. Frydman, J. (2001). Folding of newly translated proteins in vivo: the role of molecular chaperones. Annu. Rev. Biochem. 70, 603-647.

6. Laufen, T., Mayer, M. P., Beisel, C., Klostermeier, D., Mogk, A., Reinstein, J. \& Bukau, B. (1999). Mechanism of regulation of hsp70 chaperones by DnaJ cochaperones. Proc. Natl Acad. Sci. USA, 96, 5452-5457.

7. Zylicz, M., Ang, D. \& Georgopoulos, C. (1987). The Grpe protein of Escherichia-coli-purification and properties. J. Biol. Chem. 262, 17437-17442.

8. Packschies, L., Theyssen, H., Buchberger, A., Bukau, B., Goody, R. S. \& Reinstein, J. (1997). GrpE accelerates nucleotide exchange of the molecular chaperone DnaK with an associative displacement mechanism. Biochemistry, 36, 3417-3422.

9. Motohashi, K., Yohda, M., Endo, I. \& Yoshida, M. (1996). A novel factor required for the assembly of the DnaK and DnaJ chaperones of Thermus thermophilus. J. Biol. Chem. 271, 17343-17348.

10. Motohashi, K., Taguchi, H., Ishii, N. \& Yoshida, M. (1994). Isolation of the stable hexameric DnaK.DnaJ complex from Thermus thermophilus. J. Biol. Chem. 269, 27074-27079.

11. Klostermeier, D., Seidel, R. \& Reinstein, J. (1999). The functional cycle and regulation of the Thermus thermophilus DnaK chaperone system. J. Mol. Biol. 287, 511-525.

12. Pleckaityte, M., Mistiniene, E., Michailoviene, V. \& Zvirblis, G. (2003). Identification and characterization of a Hsp70 (DnaK) chaperone system from Meiothermus ruber. Mol. Genet. Genomics, 269, 109-115.

13. Schroder, H., Langer, T., Hartl, F. U. \& Bukau, B. (1993). DnaK, DnaJ and GrpE form a cellular chaperone machinery capable of repairing heat-induced protein damage. EMBO J. 12, 4137-4144.

14. Szabo, A., Langer, T., Schröder, H., Flanagan, J., Bukau, B. \& Hartl, F. U. (1994). The ATP hydrolysisdependent reaction cycle of the Escherichia coli Hsp70 system DnaK, DnaJ, and GrpE. Proc. Natl Acad. Sci. USA, 91, 10345-10349.

15. Groemping, Y., Klostermeier, D., Herrmann, C., Veit, T., Seidel, R. \& Reinstein, J. (2001). Regulation of ATPase and chaperone cycle of DnaK from Thermus thermophilus by the nucleotide exchange factor GrpE. J. Mol. Biol. 305, 1173-1183.

16. Garnier, J., Gibrat, J.-F. \& Robson, B. (1996). GOR Method for predicting protein secondary structure from amino acid sequence. In Methods in Enzymology: Computer Methods for Macromolecular Sequence Analysis: Section IV. Secondary Structure Considerations (Doolittle, R. F., ed.), vol. 266, pp. 540-553, Academic Press, CA.

17. Kelley, L. A., MacCallum, R. M. \& Sternberg, M. J. (2000). Enhanced genome annotation using structural profiles in the program 3D-PSSM. J. Mol. Biol. 299, 499-520.

18. Jaeger, J., Restle, T. \& Steitz, T. A. (1998). The structure of HIV-1 reverse transcriptase complexed with an RNA pseudoknot inhibitor. EMBO J. 17, 4535-4542.

19. Klostermeier, D., Seidel, R. \& Reinstein, J. (1998). Functional properties of the molecular chaperone DnaK from Thermus thermophilus. J. Mol. Biol. 279, 841-853.

20. Herbst, R., Gast, K. \& Seckler, R. (1998). Folding of 
firefly (Photinus pyralis) luciferase: aggregation and reactivation of unfolding intermediates. Biochemistry, 37, 6586-6597.

21. Kolb, V. A., Makeyev, E. V. \& Spirin, A. S. (1994). Folding of firefly luciferase during translation in a cell-free system. EMBO J. 13, 3631-3637.

22. Osipiuk, J. \& Joachimiak, A. (1997). Cloning, sequencing, and expression of dnaK-operon proteins from the thermophilic bacterium Thermus thermophilus. Biochim. Biophys. Acta, 1353, 253-265.

23. Bukau, B. (1993). Regulation of the Escherichia coli heat-shock response. Mol. Microbiol. 9, 671-680.

24. Yura, T. \& Nakahigashi, K. (1999). Regulation of the heat-shock response. Curr. Opin. Microbiol. 2, 153-158.

25. Georgopoulos, C., Liberek, K., Zylicz, M. \& Ang, D. (1994). Properties of the Heat-Shock Proteins of Escherichia coli and the Autoregulation of the HeatShock Response. In The Biology of Heat Shock Proteins and Molecular Chaperones (Morimoto, R. I., Tissieres, A. \& Georgopoulos, C., eds), pp. 209-249, Cold Spring Harbor Laboratory Press, Cold Spring Harbor, NY.

26. Arsene, F., Tomoyasu, T. \& Bukau, B. (2000). The heat shock response of Escherichia coli. Int. J. Food Microbiol. 55, 3-9.

27. Bucca, G., Brassington, A. M., Schonfeld, H. J. \& Smith, C. P. (2000). The HspR regulon of Streptomyces coelicolor: a role for the DnaK chaperone as a transcriptional co-repressordagger. Mol. Microbiol. 38, 1093-1103.

28. Bucca, G., Brassington, A. M. E., Hotchkiss, G., Mersinias, V. \& Smith, C. P. (2003). Negative feedback regulation of dnaK, clpB and lon expression by the DnaK chaperone machine in Streptomyces coelicolor, identified by transcriptome and in vivo DnaKdepletion analysis. Mol. Microbiol. 50, 153-166.

29. Segal, G. \& Ron, E. Z. (1996). Regulation and organization of the groE and dnaK operons in Eubacteria. FEMS Microbiol. Letters, 138, 1-10.

30. Hartl, F. U. \& Hayer-Hartl, M. (2002). Molecular chaperones in the cytosol: from nascent chain to folded protein. Science, 295, 1852-1858.

31. Craig, E. A., Eisenman, H. C. \& Hundley, H. A. (2003). Ribosome-tethered molecular chaperones: the first line of defense against protein misfolding? Curr. Opin. Microbiol. 6, 157-162.

32. Hesterkamp, T., Hauser, S., Lutcke, H. \& Bukau, B. (1996). Escherichia coli trigger factor is a prolyl isomerase that associates with nascent polypeptide chains. Proc. Natl Acad. Sci. USA, 93, 4437-4441.

33. Scholz, C., Stoller, G., Zarnt, T., Fischer, G. \& Schmid, F. X. (1997). Cooperation of enzymatic and chaperone functions of trigger factor in the catalysis of protein folding. $E M B O$ J. 16, 54-58.
34. Stoller, G., Rucknagel, K. P., Nierhaus, K. H., Schmid, F. X., Fischer, G. \& Rahfeld, J. U. (1995). A ribosomeassociated peptidyl-prolyl cis/trans isomerase identified as the trigger factor. EMBO J. 14, 4939-4948.

35. Patzelt, H., Kramer, G., Rauch, T., Schonfeld, H. J., Bukau, B. \& Deuerling, E. (2002). Three-state equilibrium of Escherichia coli trigger factor. Biol. Chem. 383, 1611-1619.

36. Deuerling, E., Schulze-Specking, A., Tomoyasu, T., Mogk, A. \& Bukau, B. (1999). Trigger factor and DnaK cooperate in folding of newly synthesized proteins. Nature, 400, 693-696.

37. Teter, S. A., Houry, W. A., Ang, D., Tradler, T., Rockabrand, D., Fischer, G. et al. (1999). Polypeptide flux through bacterial Hsp70: DnaK cooperates with trigger factor in chaperoning nascent chains. Cell, 97, 755-765.

38. Yan, W., Schilke, B., Pfund, C., Walter, W., Kim, S. \& Craig, E. A. (1998). Zuotin, a ribosome-associated DnaJ molecular chaperone. EMBO J. 17, 4809-4817.

39. Gautschi, M., Lilie, H., Funfschilling, U., Mun, A., Ross, S., Lithgow, T. et al. (2001). RAC, a stable ribosome-associated complex in yeast formed by the DnaK-DnaJ homologs Ssz1p and zuotin. Proc. Natl Acad. Sci. USA, 98, 3762-3767.

40. Gautschi, M., Mun, A., Ross, S. \& Rospert, S. (2002). A functional chaperone triad on the yeast ribosome. Proc. Natl Acad. Sci. USA, 99, 4209-4214.

41. Kramer, G., Rauch, T., Rist, W., Vorderwulbecke, S., Patzelt, H., Schulze-Specking, A. et al. (2002). L23 protein functions as a chaperone docking site on the ribosome. Nature, 419, 171-174.

42. Blaha, G., Wilson, D. N., Stoller, G., Fischer, G., Willumeit, R. \& Nierhaus, K. H. (2003). Localization of the trigger factor binding site on the ribosomal $50 \mathrm{~S}$ subunit. J. Mol. Biol. 326, 887-897.

43. Tobias, J. W., Shrader, T. E., Rocap, G. \& Varshavsky, A. (1991). The N-end rule in bacteria. Science, 254, 1374-1377.

44. Williams, R. A. D. (1992). The Genus Thermus. In Thermophilic Bacteria (Kristjansson, J. K., ed.), pp. 51-62, CRC, Boca Raton.

45. Clemons, W. M., Jr, Brodersen, D. E., McCutcheon, J. P., May, J. L., Carter, A. P., Morgan-Warren, R. J. et al. (2001). Crystal structure of the $30 \mathrm{~S}$ ribosomal subunit from Thermus thermophilus: purification, crystallization and structure determination. J. Mol. Biol. 310, 827-843.

46. Schagger, H. \& von Jagow, G. (1987). Tricine-sodium dodecyl sulfate-polyacrylamide gel electrophoresis for the separation of proteins in the range from 1 to 100 kDa. Anal. Biochem. 166, 368-379.

47. Sambrook, J., Fritsch, E. F. \& Maniatis, T. (1989). Molecular Cloning: A Laboratory Manual, Cold Spring Harbor Laboratory Press, Cold Spring Harbor, NY. 